\title{
Sensitivity of crop cover to climate variability: Insights from two Indian agro-ecoregions
}

\author{
Pinki Mondal ${ }^{\text {a,* }}$, Meha Jain ${ }^{a}$, Ruth S. DeFries ${ }^{a}$, Gillian L. Galford ${ }^{b}$, Christopher Small ${ }^{c}$ \\ ${ }^{a}$ Department of Ecology, Evolution and Environmental Biology, Columbia University, New York, NY 10027, USA \\ ${ }^{\mathrm{b}}$ Gund Institute for Ecological Economics, Rubenstein School of Environment and Natural Resources, University of Vermont, VT 05405, USA \\ ${ }^{c}$ Lamont-Doherty Earth Observatory, Columbia University, Palisades, NY 10964, USA
}

\section{A R T I C L E I N F O}

\section{Article history:}

Received 7 June 2013

Received in revised form

13 February 2014

Accepted 25 February 2014

Available online $\mathrm{xxx}$

\section{Keywords:}

Agriculture

Climate sensitivity

Crop productivity

MODIS EVI

Small-holder farmers

South Asia

\begin{abstract}
A B S T R A C T
Crop productivity in India varies greatly with inter-annual climate variability and is highly dependent on monsoon rainfall and temperature. The sensitivity of yields to future climate variability varies with crop type, access to irrigation and other biophysical and socio-economic factors. To better understand sensitivities to future climate, this study focuses on agro-ecological subregions in Central and Western India that span a range of crops, irrigation, biophysical conditions and socioeconomic characteristics. Climate variability is derived from remotely-sensed data products, Tropical Rainfall Measuring Mission (TRMM precipitation) and Moderate Resolution Imaging Spectroradiometer (MODIS - temperature). We examined green-leaf phenologies as proxy for crop productivity using the MODIS Enhanced Vegetation Index (EVI) from 2000 to 2012. Using both monsoon and winter growing seasons, we assessed phenological sensitivity to inter-annual variability in precipitation and temperature patterns. Inter-annual EVI phenology anomalies ranged from $-25 \%$ to $25 \%$, with some highly anomalous values up to $200 \%$. Monsoon crop phenology in the Central India site is highly sensitive to climate, especially the timing of the start and end of the monsoon and intensity of precipitation. In the Western India site, monsoon crop phenology is less sensitive to precipitation variability, yet shows considerable fluctuations in monsoon crop productivity across the years. Temperature is critically important for winter productivity across a range of crop and management types, such that irrigation might not provide a sufficient buffer against projected temperature increases. Better access to weather information and usage of climate-resilient crop types would play pivotal role in maintaining future productivity. Effective strategies to adapt to projected climate changes in the coming decades would also need to be tailored to regional biophysical and socio-economic conditions.
\end{abstract}

(c) 2014 Elsevier Ltd. All rights reserved.

\section{Introduction}

Agriculture is the largest employment sector in India, ranging from traditional village farming to modern agriculture, with 55\% of the working population relying directly on agriculture for sustenance and livelihoods (Government of India, 2013). Food production, and thus food security, is highly impacted by seasonal weather and long term climate change, including changes in temperature (Peng et al., 2004; Lobell and Burke, 2008; Lobell et al. 2012; Jalota et al., 2013) and precipitation (Kumar et al., 2004; Cramer, 2006; Asada and Matsumoto, 2009; Byjesh et al., 2010; Auffhammer et al., 2012; Barnwal and Kotani, 2013; Jalota et al.,

\footnotetext{
* Corresponding author. Tel.: +1 212854 9987; fax: +1 2128548188.

E-mail address: pm2658@columbia.edu (P. Mondal).
}

2013). Indian smallholder farmers who own less than 2 ha of farmland represent $78 \%$ of the total Indian farmers and produce $41 \%$ of the country's food crops. These smallholder farmers are among some of the most vulnerable communities to climatic and economic changes due to limited access to technology, infrastructure, markets, and institutional or financial support in the case of adverse climatic events (Singh et al., 2002).

Both inter-annual and long-term climate variability affect food production in India (Selvaraju, 2003; Kumar et al., 2004; Guiteras, 2007; Revadekar and Preethi, 2012). The El Niño Southern Oscillation (ENSO) and the Indian Ocean Dipole (IOD) impact differential heating of the Indian Ocean, which disrupts the typical onset of the Indian monsoon (Wu and Kirtman, 2004, Sankar et al., 2011). A warm ENSO phase results in an average agricultural loss of US\$773 million, whereas a cold ENSO year leads to an average financial gain of US\$437 million (Selvaraju, 2003). In addition to these episodic 
events, historical records indicate that winter precipitation has significantly increased for all of India since 1954, yet monsoon precipitation has decreased over most regions (Pal and Al-Tabba, 2011; Subash et al., 2011). Recent research indicates that a less frequent but intense monsoon could have a negative impact on crop productivity (Auffhammer et al., 2012).

Extreme precipitation events ( $>40 \mathrm{~mm} /$ day) across all of India are projected to increase in frequency in the second half of this century based on findings from the Coupled Model Intercomparison Project 5 (CMIP5) (Chaturvedi et al., 2012). Annual precipitation is projected to increase between $4 \%$ and $14 \%$ for all of India by 2080 given "business as usual" parameterizations (Chaturvedi et al., 2012). The potential benefits of any increased precipitation on water-limited crops through direct water supply and increased storage of irrigation water, however, could be offset by projected increases in temperature (Peng et al., 1995; Wheeler et al., 2000). Long-term records show that winter temperatures have increased but there have only been non-significant increases in monsoon temperatures (Pal and Al-Tabba, 2010; Subash et al., 2011). By the 2080s, annual temperatures are expected to increase by $1.7{ }^{\circ} \mathrm{C}-4.8^{\circ} \mathrm{C}$ according to the CMIP5 models (Chaturvedi et al., 2012).

Historically, India has demonstrated the capacity to adapt new practices and technologies to increase agricultural production and decrease vulnerability to climate variability. The 'Green Revolution' benefited the Indian agricultural sector in many ways, introducing irrigation, fertilizers, and high-yielding crop varieties (Freebairn, 1995). Many argue that the benefits focused on already advantaged large-scale farmers in north-western India, while small-scale farmers in other regions only marginally benefited (Freebairn, 1973; Shiva, 1991; Das, 1999). These small-scale farmers typically rely on climate-dependent irrigation such as canal irrigation and shallow dug-wells, and do not always have access to high yielding crop varieties; they are thus at a greater risk to variations in climate (Singh et al., 2002). Excessive use of groundwater irrigation in the north-western part of India has led to severe groundwater depletion (Rodell et al., 2009), and is likely to affect future crop productivity in the absence of effective adaptation strategies, such as new drought-tolerant crop varieties, access to other forms of irrigation (e.g. canal irrigation), better and effective storage of monsoon precipitation, and access to timely weather information to inform planting strategies (Singh et al., 2002). Baseline information on agricultural sensitivity to climate variability could provide useful information for farm-level strategies and policies that promote adaption to climate variability. We must therefore first understand how, and to what degree, crops in different regions in India respond to current temperature and precipitation variability.

Crop responses to intra- and inter-annual climate variability have been widely assessed using remotely sensed vegetation indices, which can accurately capture cropping patterns, including crop phenology, crop type, and cropping intensity (Xiao and Moody, 2004; Sakamoto et al., 2006, 2009; Prasad et al., 2007; Wardlow and Egbert, 2008; Tao et al., 2008; Lobell et al., 2012). The Moderate Resolution Imaging Spectroradiometer (MODIS)derived data products, in particular, have been used to examine several different crop pattern parameters, such as identifying cropping rotation (Morton et al., 2006; Sakamoto et al., 2006; Brown et al., 2007; Galford et al., 2008, 2010; Wardlow and Egbert, 2008), quantifying crop area coverage (Biradar and Xiao, 2011; Pan et al., 2012), documenting crop-related land use practices (Wardlow and Egbert, 2008), classifying specific crop types (Wardlow et al., 2007; Hatfield and Prueger, 2010; Ozdogan, 2010; Pittman et al., 2010), and monitoring crop phenology (Sakamoto et al., 2005, 2006; Wardlow et al., 2006). MODIS data products have been preferred for such applications due to their moderate spatial resolutions $(250,500,1000 \mathrm{~m})$, high temporal resolutions (16-day composites for the vegetation index products), and global coverage. Although the spatial resolution of MODIS presents challenges to identify crop patterns in small-scale farms ( $\leq 2 \mathrm{ha}$ ), the possibility of achieving moderately high accuracy and the ease of implementation at regional scales offer considerable potential for time-series analysis of crop cover (Jain et al., 2013).

India is a highly heterogeneous country in terms of environmental characteristics. Annual precipitation in India varies from a few centimeters in western Indian deserts to several hundred centimeters in the northeastern mountainous regions of India. Temperature can vary from less than $-40{ }^{\circ} \mathrm{C}$ in the Himalayas to over $50{ }^{\circ} \mathrm{C}$ in western India. In addition, a highly variable topography across India has resulted in a great variety of soils. In order to identify relatively homogeneous regions in terms of soil, climate, physiography and moisture availability periods for crop growth, India has been grouped into 20 agro-ecoregions (Fig. 1) that have been further divided into 60 agro-eco subregions (Gajbhiye and Mandal, 2000).

Previous crop-modeling studies have projected changes in crop yield based on different climate model-generated scenarios (Lal, 2011). These models generally focus on bio-physical characteristics of crop responses to changing climate in a larger region. Few studies have assessed the relative agricultural sensitivity to changing climate among different agro-eco subregions that differ in their access to irrigation, source of irrigation (groundwater vs. surface irrigation), crop type (food crops vs. cash crops), and market access. Better understanding of the potential and constraints in each of these agro-eco subregions will help formulate effective strategies to adapt to a changing climate.

The aim of this study is to quantify decadal changes in seasonal crop covers and identify, compare and contrast agricultural sensitivity to inter-annual climate variability in two Indian agro-eco subregions. We use satellite-derived Enhanced Vegetation Index (EVI) to capture heterogeneity in crop cover across space and time. The term 'crop cover' in this study includes both crop greenness (a measure for crop productivity) and crop extent (or field area), since the EVI value at the pixel level can be influenced by both. We address the following questions in this study:

1. Which climate variables (precipitation and temperature) most influence crop cover for monsoon and winter crops from 2000 to 2012 in the two study regions?

2. How does the sensitivity of crop cover to climate variability vary in different agro-ecological regions with different socioeconomic factors?

We first quantified seasonal peak EVI values and anomalies in crop cover at the pixel level (2000-2012). We then constructed mixed-effect models to identify the most important climate variables for crop cover for each season in each of the study sites. With these results, we discussed the relative climate sensitivity in the context of socio-economic characteristics of these two regions.

\section{Materials and methods}

\subsection{Study sites}

We selected two sites from different agro-ecological subregions in central and western India (Fig. 1) based on our long-term research experience in these regions, thus enabling us to better interpret the findings. These sites represent a variety of demographic characteristics (Table S1), cropping practices (Table S1), precipitation range (Fig. 2), irrigation access (Fig. 3), and market dependence that is typical of the Indian agricultural sector (Fan 

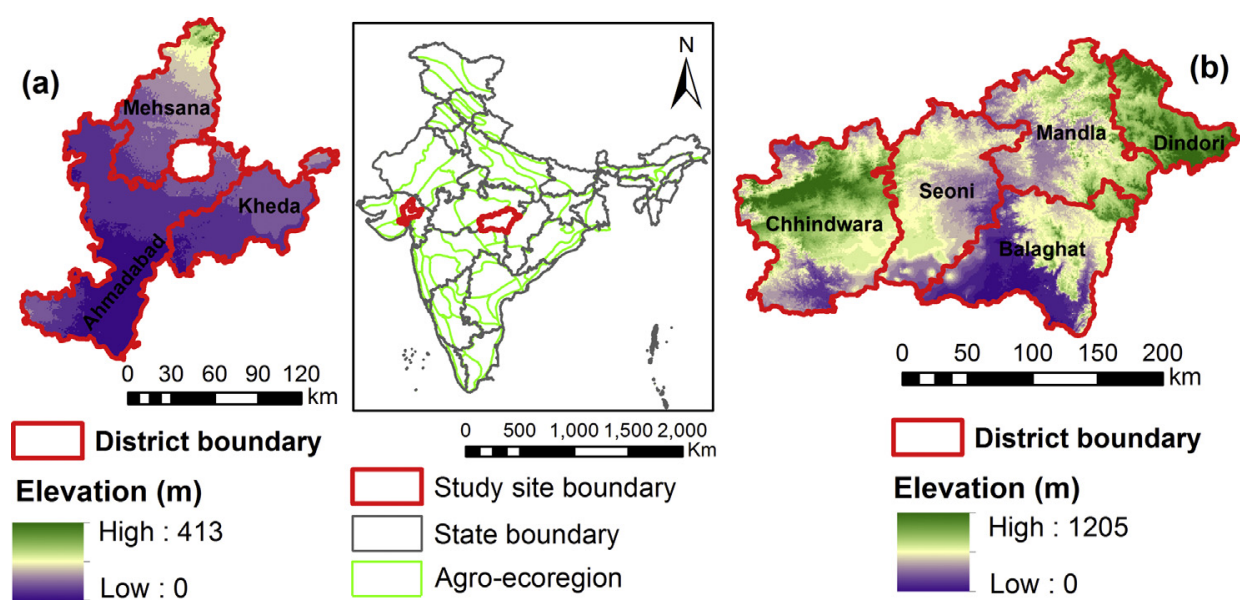

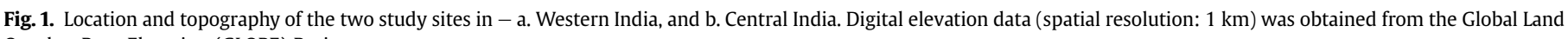
One-km Base Elevation (GLOBE) Project.

Source: NOAA, 2013.

et al., 2000; Gajbhiye and Mandal, 2000; O’Brien et al., 2004). The Central India site encompasses five districts in the state of Madhya Pradesh, namely Balaghat, Chhindwara, Seoni, Dindori, and Mandla, covering a total of $43,072 \mathrm{sq}$. $\mathrm{km}$. The site is located within the "hot moist sub-humid" agro-ecological subregion that covers Satpura range and Wainganga valley. This subregion has a shallow to deep loamy to clayey, mixed red and black soil type (agro-eco region: 10; see Gajbhiye and Mandal, 2000 for details). This site receives an average monsoon rainfall of $1225 \mathrm{~mm}$ with an average of $30 \mathrm{~mm}$ of winter rainfall (Fig. 2), has little to moderate access to irrigation (Fig. 3) through surface canals and shallow tanks and wells, and produces predominantly food crops (rice, wheat, pulses) for local consumption and local markets. Rice and wheat are respectively the main monsoon and winter crops in most parts of this ecological subregion.

The Western India site spans three districts in the state of Gujarat - Ahmadabad, Kheda, and Mehsana, covering a total area of 16,461 sq. km. This "hot dry semi-arid" ecological subregion covers the north Gujarat Plain (agro-eco region: 4; see Gajbhiye and Mandal, 2000 for details), and has a deep loamy, gray-brown soil type. In contrast to the Central India site, this site receives low monsoon rainfall (approximately $840 \mathrm{~mm}$ - Fig. 2) with little or no
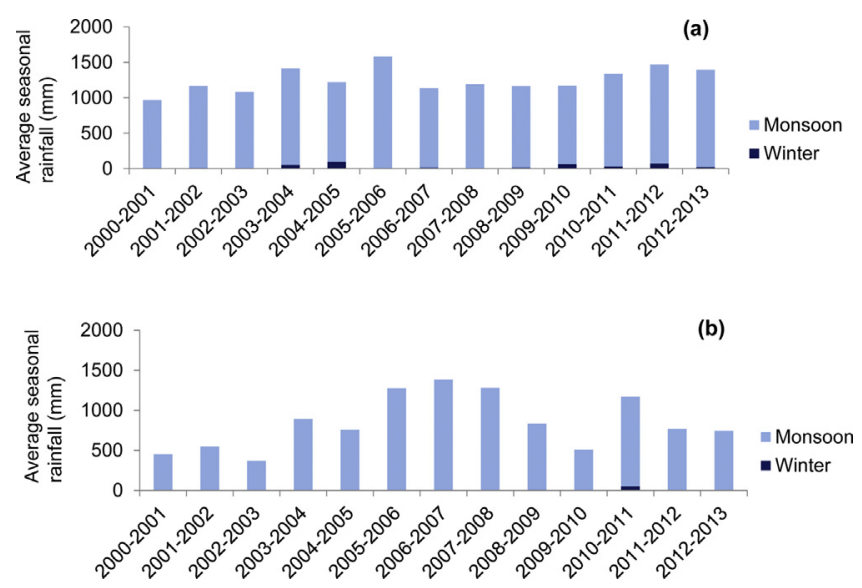

Fig. 2. Seasonal precipitation in - a. Central India and b. Western India study sites from 2000 to 2013. Monsoon precipitation was calculated for May to October during 2000-2012. Winter precipitation was calculated for November to January from 20002001 to $2012-2013$. winter rainfall, produces both food (wheat, pulses, maize) and cash (cotton, castor) crops, is highly irrigated (Fig. 3) through groundwater and surface canals, and is very market-oriented (Dubash, 2002; Gajbhiye and Mandal, 2000). Rice, cotton, and castor are the main monsoon crops, while wheat, rice, and potato are the main winter crops in this subregion.

\subsection{Phenological data}

MODIS EVI data products (May 2000-March 2013, $250 \mathrm{~m}$ ) were obtained from the IRI/LDEO Data Library (IRI/LDEO Data Library, 2013). The data are spatial and temporal composites of only the most cloud-free daily values over a 16-day period from MODIS (Huete et al., 2002). We preferred EVI over other remotely-sensed vegetation indices as it better adjusts for background soil and canopy reflectances (Huete et al., 2002). The EVI time-series was smoothed using a cubic smoothing spline function to correct for any remaining high-frequency noise, such as from clouds (Jain et al., 2013). Then we clipped the EVI time-series for monsoon and winter seasons. The monsoon season was defined as May 8 to November 15 and the winter crop season was defined as December 2 through March 21 based on our field experience, crop calendar (Ministry of Agriculture, 2010), and MODIS phenology (Fig. S1).
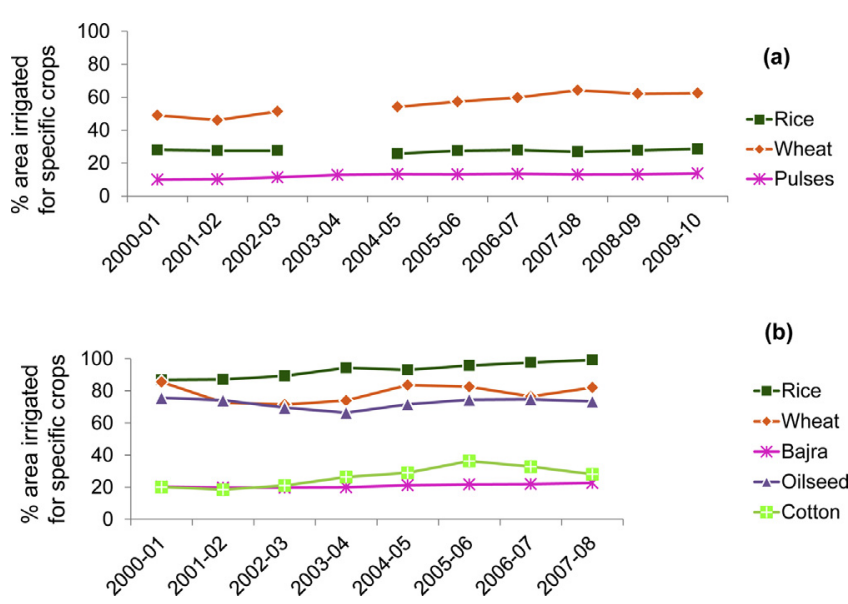

(b)

$$
\begin{aligned}
& \text { - - -Rice } \\
& \text { - -Wheat } \\
& \text { *-Bajra } \\
& \text {---Oilseed } \\
& \text { - }- \text {-Cotton }
\end{aligned}
$$

Fig. 3. Crop-wise area irrigated in - a. Central India (2000-2010) and b. Western India study sites (2000-2008).

Source: IndiaStat, 2013 
Table 1

Detailed description of climate variables used in the study.

\begin{tabular}{|c|c|}
\hline Climate variables & Description \\
\hline Wetstart & $\begin{array}{l}\text { Wet season start date }{ }^{\text {a }} \text { First wet day }\left(>1 \mathrm{~mm} \text { ) of first } 5 \text {-day wet spell (wet spell amount } \geq \mu_{13 \text {-year wet season }}{ }^{*} 5\right) \text { which is not } \\
\text { immediately followed by } 10 \text {-day dry spell with }<10 \mathrm{~mm} \text { (to exclude false start) }\end{array}$ \\
\hline Wetend & $\begin{array}{l}\text { Wet season end date: Last wet day }(>1 \mathrm{~mm} \text { ) of last } 5 \text {-day wet spell which is NOT immediately preceded by } 10 \text {-day dry spell with } \\
<10 \mathrm{~mm} \text { (to exclude post-monsoon short spell) }\end{array}$ \\
\hline Wetlen & Wet season length: Wet season end date - Wet season start date \\
\hline Monrainy & Number of monsoon rainy days: monsoon days between first wet day and last wet day with $\mu_{\text {daily }} \geq \mu_{13 \text {-year wet season }}$ \\
\hline Mondry & 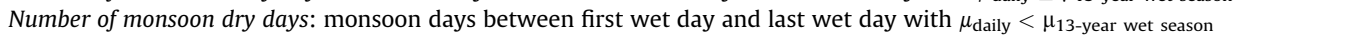 \\
\hline Monnorain & Number of monsoon days with no rainfall: monsoon days between first wet day and last wet day with $\mu_{\text {daily }}=0$ \\
\hline Totalmonrain & Total monsoon rainfall: ( $\Sigma$ rainfall ${ }_{\text {daily }}$ ) (for wet season start date to wet season end date) \\
\hline SDII & Simple Daily Intensity Index: Total monsoon rainfall/number of monsoon rainy days \\
\hline Winrainy & Number of winter rainy days: Number of $\mathrm{NDJ}^{\mathrm{b}}$ winter days with $\mu_{\text {daily }} \geq \mu_{13 \text {-year dry season }}$ \\
\hline MonTmax & Monsoon daytime temperature max: $\left(\Sigma \mu_{\text {monthly }}\right) / 3$ (for $\mathrm{JJA} \mathrm{A}^{\mathrm{b}}$ maximum temperature in ${ }^{\circ} \mathrm{C}$ ) \\
\hline MonTmin & Monsoon daytime temperature min: $\left(\Sigma \mu_{\text {monthly }}\right) / 3$ (for JJA minimum temperature in ${ }^{\circ} \mathrm{C}$ ) \\
\hline MonTmean & Monsoon daytime temperature mean: $\left(\Sigma \mu_{\text {monthly }}\right) / 3$ (for JJA mean temperature in ${ }^{\circ} \mathrm{C}$ ) \\
\hline MonTrange & Monsoon daytime temperature range: Winter temperature max-Winter temperature min \\
\hline MonNTmax & Monsoon nighttime daytime temperature max: $\left(\Sigma \mu_{\text {monthly }}\right) / 3$ (for JJA maximum temperature in ${ }^{\circ} \mathrm{C}$ ) \\
\hline MonNTmin & Monsoon nighttime temperature min: $\left(\Sigma \mu_{\text {monthly }}\right) / 3$ (for JJA minimum temperature in ${ }^{\circ} \mathrm{C}$ ) \\
\hline MonNTmean & Monsoon nighttime temperature mean: $\left(\Sigma \mu_{\text {monthly }}\right) / 3$ (for JJA mean temperature in ${ }^{\circ} \mathrm{C}$ ) \\
\hline MonNTrange & Monsoon nighttime temperature range: Winter temperature max-Winter temperature min \\
\hline WinTmax & Winter daytime temperature max: $\left(\Sigma \mu_{\text {monthly }}\right) / 3$ (for NDJ maximum temperature in ${ }^{\circ} \mathrm{C}$ ) \\
\hline WinTmin & Winter daytime temperature min: $\left(\Sigma \mu_{\text {monthly }}\right) / 3$ (for NDJ minimum temperature in ${ }^{\circ} \mathrm{C}$ ) \\
\hline WinTmean & Winter daytime temperature mean: $\left(\Sigma \mu_{\text {monthly }}\right) / 3$ (for NDJ mean temperature in ${ }^{\circ} \mathrm{C}$ ) \\
\hline WinTrange & Winter daytime temperature range: Winter temperature max-Winter temperature min \\
\hline WinNTmax & Winter nighttime temperature max: $\left(\Sigma \mu_{\text {monthly }}\right) / 3$ (for NDJ maximum temperature in ${ }^{\circ} \mathrm{C}$ ) \\
\hline WinNTmin & Winter nighttime temperature min: $\left(\Sigma \mu_{\text {monthly }}\right) / 3$ (for NDJ minimum temperature in ${ }^{\circ} \mathrm{C}$ ) \\
\hline WinNTmean & Winter nighttime temperature mean: $\left(\Sigma \mu_{\text {monthly }}\right) / 3$ (for NDJ mean temperature in ${ }^{\circ} \mathrm{C}$ ) \\
\hline WinNTrange & Winter nighttime temperature range: Winter temperature max-Winter temperature min \\
\hline
\end{tabular}

a January 1 is counted as Day 1.

b $\mathrm{NDJ}=$ November-December-January, JJA = June-July-August.

A pixel was defined to have a peak if the EVI time series had an inflection point with a local maximum during the season of interest (Fig. S2). Two masks were applied on the time-series - a) the first one masked any MODIS pixel without a peak in EVI phenology (Fig. S2) in any year of the time-series (i.e. pixels that were never cropped), and b) the second one masked non-agricultural pixels, including scrubland, forest, bare land and urban areas using the Random Forest classification algorithm (Breiman, 2001; Jain et al., 2013). For unmasked pixels, we determined the peak EVI value for each season, and each year for 2000-2012. In the absence of a peak in a particular year, the algorithm returned the EVI value for pre-specified dates (monsoon: September 4 and winter: January 24). If the pixels were 'cropped', these dates are most likely to capture the most representative EVI values. In absence of a peak, these pixels will represent either a 'failed crop' or a fallow pixel. The peak MODIS values were then spatially aggregated to match the extent of the climate variables $\left(0.25^{\circ}\right.$ - see Section 2.3 for details), which is the coarsest spatial resolution of datasets used for this study. We also calculated the seasonal EVI anomaly $\left(\mathrm{EVI}_{\sigma}\right)$ as: $\left[\left(\left(E I_{\alpha} / E I_{\mu}\right)-1\right)^{*} 100\right]$, where $E I_{\alpha}$ are the peak EVI values and $\mathrm{EVI}_{\mu}$ are long-term seasonal means.

\subsection{Climate variability}

We used the Tropical Rainfall Measuring Mission (TRMM) dataset from the IRI data library (IRI/LDEO Data Library, 2013) to calculate precipitation-related variables. Data were obtained for monsoon (May-October) and winter (November-January) precipitation for each of the study sites. These datasets represent compiled daily precipitation values in $\mathrm{mm}$ with a spatial resolution of $0.25^{\circ}$ ( $\sim 27.83 \mathrm{~km}$ at equator). We selected nine precipitation variables to be calculated on these datasets, namely wet season start date, wet season end date, wet season length, number of monsoon rainy days, number of monsoon dry days, number of monsoon days with no rainfall, total monsoon rainfall, simple daily intensity index, and number of winter rainy days based on existing literature (Mearns et al., 1996; Kumar et al., 2004; Gadgil and Kumar, 2006; Chen et al., 2013) and personal communication with the farmers. A detailed description of these variables has been provided in Table 1. All nine variables were considered as predictors in models for both seasons for each of the 13 years, except the number of winter rainy days, which was considered only for winter season models.

To calculate temperature variables, we used the MODIS land surface temperature (LST) dataset (MOD11A2) from the NASA LPDAAC (USGS, 2013) for both monsoon and winter seasons. This dataset is an 8-day composite of average values of clear-sky LST with a sinusoidal projection and a spatial resolution of $1 \mathrm{~km}$. The data were rescaled to convert to units of degree Celsius and reprojected to WGS-84 coordinate system. Both the daytime and nighttime LST values from the re-projected and rescaled datasets were used to calculate a total of sixteen temperature variables (Table 1). All these datasets were then aggregated to TRMM pixel level.

\subsection{Mixed-effect model}

All of the explanatory variables (section 2.3) were standardized using the following formula: $x_{z}=\left(x_{i}-\mu\right) / \sigma$, where $x_{z}$ is the standardized value of a particular pixel, $x_{i}$ is the original value of that pixel, $\mu$ is the 13 -year mean, and $\sigma$ is the standard deviation. Some of the climate variables showed a high degree of multicollinearity (Table S2), and were excluded from further analyses. Pearson's $r$ was used as a measure for correlation, and a cut-off value of 0.6 was used to exclude collinear variables with maximum possible variable retention. Final sets of variables used for each study area are listed in Table 2. Intra-class correlation (ICC) (Kreft and DeLeeuw, 1998) was calculated to determine if random effects are present in the dataset, and if a linear mixedeffect model should be used to explain the climate dependence of agricultural productivity (See Supplementary Information for details). 
Table 2

Final set of climate variables used in the statistical models after excluding multicollinear variables.

\begin{tabular}{lll}
\hline Study site & Season & Final set of variables \\
\hline Central India & Monsoon & $\begin{array}{l}\text { Wetstart, wetend, totalmonrain, SDII, } \\
\text { monnorain, monTmean, monTrange, } \\
\text { monNTmean, monNTrange }\end{array}$ \\
& Winter & $\begin{array}{l}\text { Wetstart, wetend, totalmonrain, SDII, } \\
\text { monnorain, winrainy, winTmean, } \\
\text { winTrange, winNTmean, winNTrange }\end{array}$ \\
& Wetstart, monrainy, mondry, SDII, \\
Western India & monTmean, monTrange, monNTmax, \\
& WonNTmean \\
& Wetstart, monrainy, mondry, SDII, \\
& & wintainy, winTmean, winTrange, \\
& & winNTmean, winNTrange \\
\hline
\end{tabular}

Random effects for the 'district' variable ranged between $24 \%$ and $56 \%$ for monsoon, and over $50 \%$ for winter (See Supplementary Information for details), based on which linear mixed-effect models were used to address variations across different districts and across different pixels within each district. The Central and Western India sites have sample sizes of 832 (64 for each year) and 351 (27 for each year) respectively. The peak EVI values for each pixel were used as the independent variable in the mixed-effect models, while we also used descriptive statistics to explain EVI anomalies across the two study sites. Multiple mixed-effect models were run with different combinations of predictor variables for each of the study areas for each season. The Akaike Information Criterion (AIC) (Akaike, 1974), which is a measure of the relative quality of each statistical model considering both goodness of fit and minimization of parameters, was used to select the final models for each season and study site combination.

\section{Results}

\subsection{Crop cover anomalies}

\subsubsection{Monsoon season}

Monsoon EVI anomaly in both sites shows considerable variability across space and time. Fig. 4 illustrates the range of TRMM-level seasonal EVI anomaly for each year. In the Central India site, monsoon anomaly varies between $-20 \%$ and $20 \%$ of the 13 -year mean, with the greatest negative anomaly (i.e. lowest median crop cover) in 2012 (Fig. 4a). The years 2003, 2007, and 2010 had higher EVI as revealed by approximately $10 \%$ more crop cover than the 13-year mean (Fig. 4a). Inter-annual variability in this site is lower than that in the Western India site. Monsoon EVI anomaly in the Western India site varies between $-25 \%$ and $20 \%$ of the 13-year mean (Fig. 4b). The years 2003, 2007, and 2010 show more crop cover than other years in the Western India site as well. But unlike the Central India site, the median values are lower than $10 \%$ in low production years such as 2002, 2004, and 2012 (Fig. 4b).

\subsubsection{Winter season}

For winter seasons both of our study sites show greater variability than the monsoon season, both within each year and across the years. Overall variability ranges from $-25 \%$ to $25 \%$ for both sites (Fig. 4c, d). Some pixels in the Central India site recorded high anomalies up to $200 \%$ (not shown in the figure). The winter seasons of 2003-04 and 2009-10 were particularly high crop cover years for the Central India site with approximately $10 \%$ more cover than the 13 -year mean value (Fig. $4 \mathrm{c}$ ). The winter season of 2000-01 showed the lowest crop cover for this site. In the Western India site the anomaly shows a somewhat upward trend (Fig. 4d), with the maximum positive anomaly in
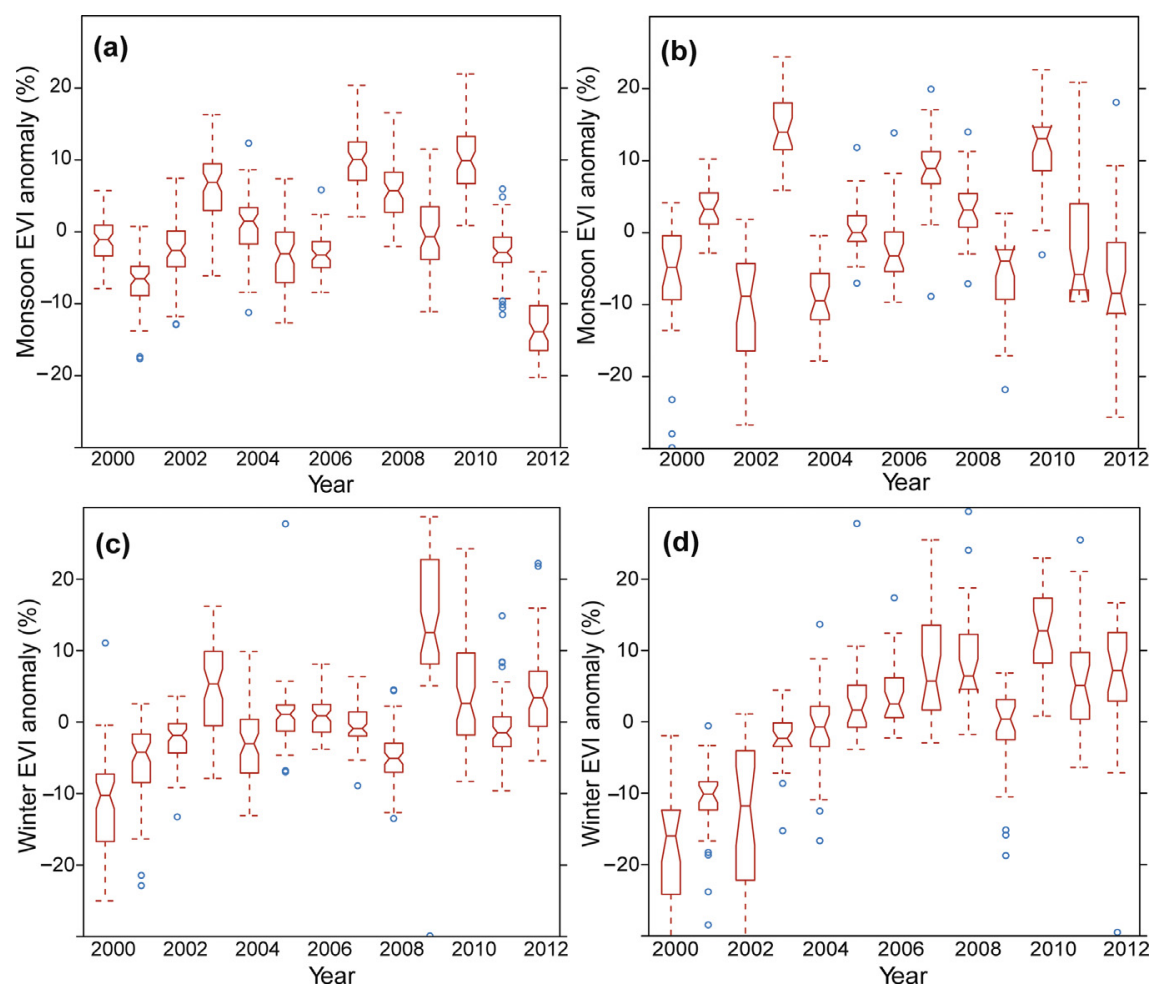

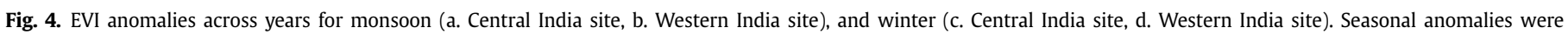
calculated as percent deviations from 13-year seasonal mean. 

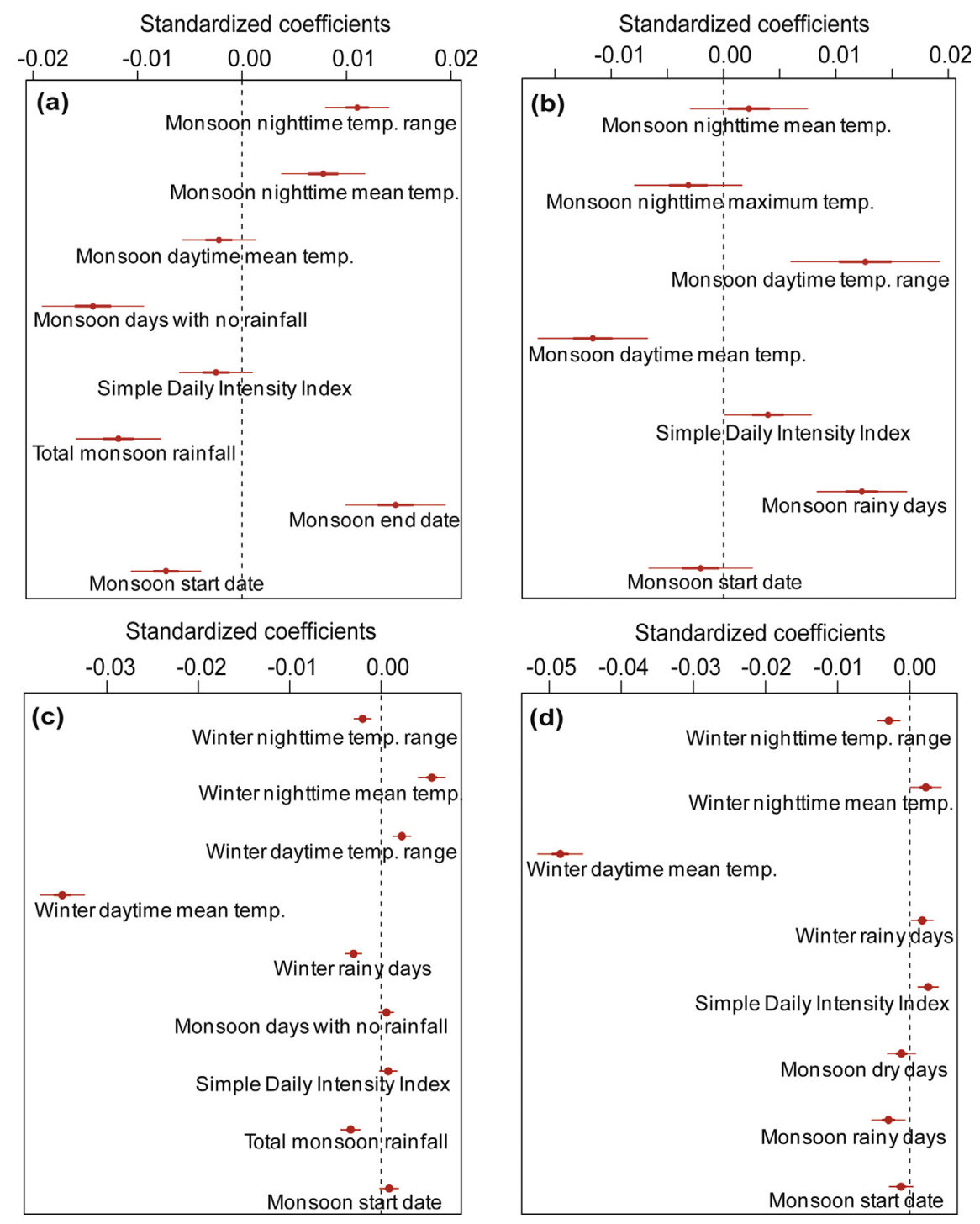

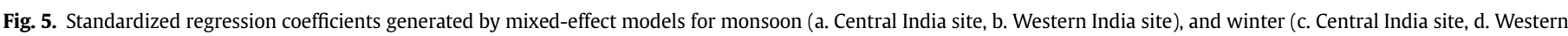
India site).

2010-11 and the minimum negative anomaly in 2000-01. The year 2009-10, which was a high crop cover year for the Central India site, was the lowest cover year for Western India since 2004-05.

\subsection{Relative importance of climate variables}

\subsubsection{Monsoon season models}

The best mixed-effect models based on the lowest AIC values for each study site reveal little commonalities in the list of the most influential climate variables for monsoon crop cover (Fig. 5). Among the eight climate variables selected in the best monsoon model for the Central India site (Fig. 5a), monsoon end date was the most important (Fig. 6a), closely followed by monsoon days with no rainfall, total monsoon rainfall, and monsoon start date. Among temperature variables, nighttime variables were more influential. All the variables, except monsoon end date and nighttime temperatures, have inverse relationships with monsoon peak EVI values. According to the best monsoon model for the Western India site, daytime temperature range, number of monsoon rainy days, and daytime mean temperature variables are the most closely related ones to monsoon crop cover (Figs. 5b and 6b). Monsoon start date, mean daytime temperature, and maximum nighttime temperature have inverse relationships with monsoon peak EVI values in the Western India site.

\subsubsection{Winter season models}

For both sites, winter daytime mean temperature is the overwhelmingly important variable despite the differences in biophysical and socio-economic conditions (Fig. 6c, d). In the Central India site, total amount and intensity of monsoon rainfall, and winter rainy days are the most important climate parameters for winter peak EVI values other than the temperature variables (Fig. 5c). The number of winter rainy days, which has a negative impact on winter crop cover in the Central India site, has slightly positive impact on winter crop cover in the Western India site (Fig. 5c, d). Monsoon start date and number of monsoon rainy days were more important for winter crop cover in the Western India site other than the day and nighttime temperature (Fig. 5d). 

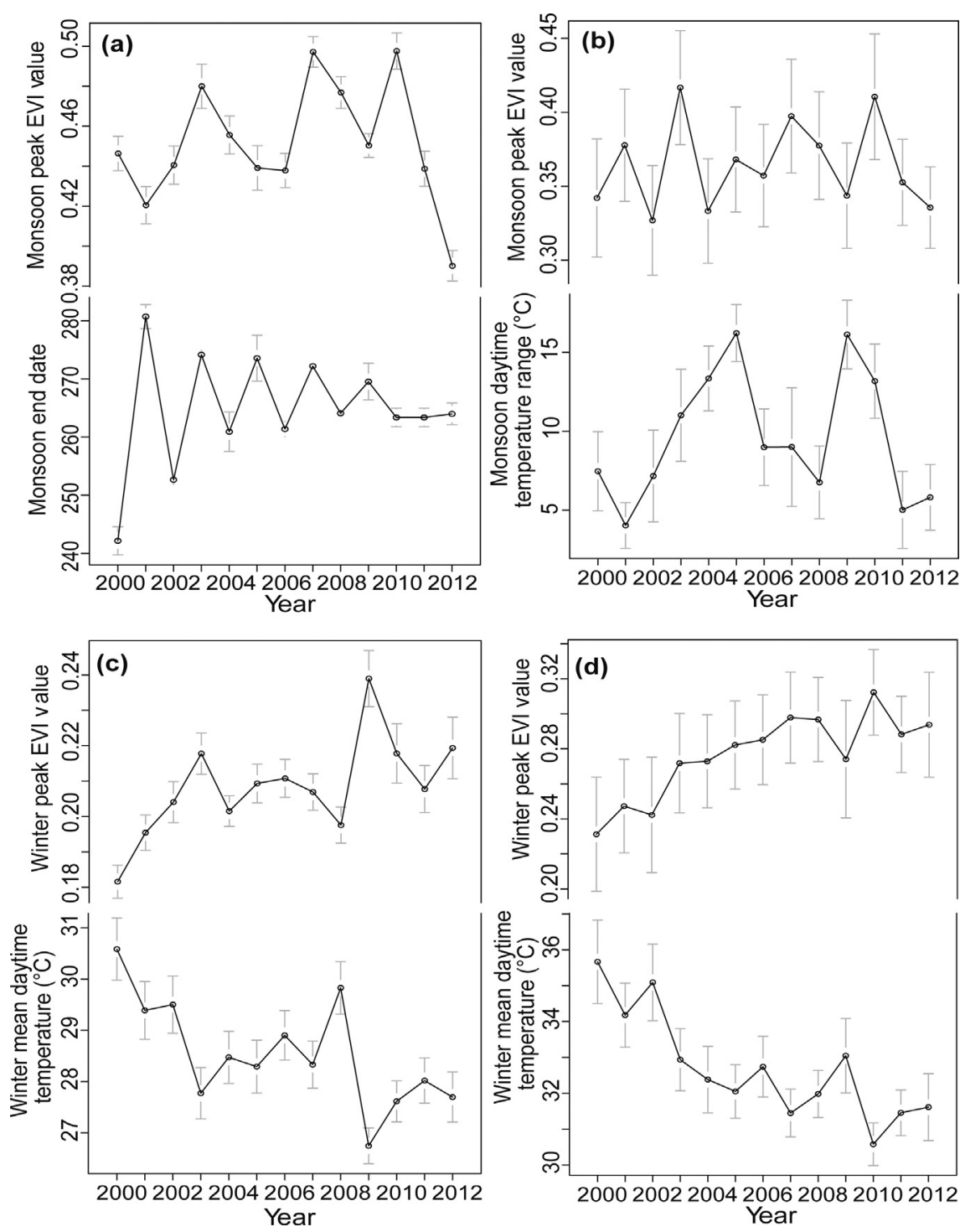

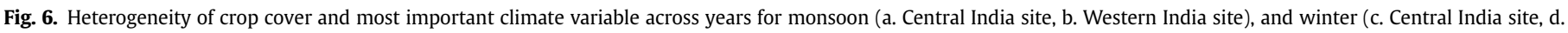
Western India site). Each year has a sample size of 64 for the Central India site and 27 for the Western India site.

\section{Discussion}

\subsection{Central India site}

Crop cover in the Central India site shows a close relationship with several temperature and precipitation variables. Especially in the monsoon, an overall decrease in precipitation will severely affect crop production as was seen during the recent drought year of 2012 (Fig. 4a). Our findings also suggest that crop cover in this site tends to rely more on the combined effects on monsoon start and end date, monsoon days with no rainfall and intensity of rainfall, rather than total monsoon rainfall alone. The year 2011 was one of the highest average monsoon rainfall years in the past decade (Fig. 2). Crop cover in that year, however, shows a slightly negative anomaly compared to the 13 -year mean (Fig. 4a), which might be attributed to a rather late monsoon start date (Fig. S3). The mixed-effect model suggests an inverse relationship between total monsoon rainfall and crop cover (Fig. 5a) that seems counterintuitive, since rice requires a substantial amount of water either from direct precipitation or through irrigation. This might be explained by the fact that a late monsoon start date can severely affect the vegetative phase of the rice crop through a transplantation shock (Gadgil and Kumar, 2006), leading to an overall production deficit even in case of a higher total monsoon precipitation. An average of only $30 \%$ of total rice fields are irrigated in the Central India site (Fig. 3), hence precipitation timing will play a critical role in future monsoon crop production in the absence of irrigation.

The monsoon crop in the Central India site is negatively affected by higher mean daytime temperature, but is positively correlated to mean nighttime temperature and nighttime temperature range (Fig. 5a). These findings suggest that the ultimate crop reaction pathways will be determined by both absolute temperature increases and intra-seasonal temperature fluctuations. Crops often respond differently to seasonal temperature range depending on the combined positive effects of increasing temperature before dormancy and negative effects of increasing temperature after dormancy (Chen et al., 2013). Since most climate models have projected an increase in both maximum and minimum temperature in the future decades, future crop productivity can be seriously impacted in absence of more heattolerant crop varieties. 
The primary winter crops in the Central India site are wheat and pulses with very different water requirement as shown by their irrigation coverage (Fig. 3). Wheat requires moderate amount of water, especially during the growing phase, and soil moisture alone is not enough to get high wheat yields. Frequent winter rainy days and/or access to irrigation can help increase wheat productivity. Pulses, on the other hand, can thrive on soil moisture stored from monsoon precipitation, and do not need considerable amounts of irrigated water (Fig. 3) in the absence of winter precipitation. Besides, excessive water through frequent or intense winter rainy days early in the season could decrease pulse productivity (Mondal, personal observation). Approximately $50-60 \%$ of wheat fields in this site receive irrigated water (Fig. 3), and the rest of the fields still rely only on winter precipitation, which can be highly variable in this area (Fig. 2). Moreover, winter crop cover is highly sensitive to mean daytime temperature (Fig. 6c). The years of 2003, 2004, 2009, and 2011 received above average winter rainfall in this site (Fig. 2), while only 2003 and 2009 witnessed an increase in crop cover (Fig. 4c) likely due to relatively lower mean temperature compared to 2004 and 2011 (Fig. 6c). Wheat productivity is known to be sensitive to temperature (Lobell et al., 2012), besides higher temperature would reduce soil moisture, thus affecting the productivity of pulses as well. In a mostly climate-dependent agricultural system such as this Central India site, access to irrigation can play a critical role in winter food production. Supplemental irrigation is known to improve rain-fed wheat yields in China even with increasing temperature (Guoju et al., 2005). It remains unknown, however, if the existing irrigation network in Central India could effectively buffer against the projected increase in winter temperature in the coming decades.

\subsection{Western India site}

In the Western India site, crop cover is impacted by several climate factors, particularly during the monsoon season. Overall, temperature parameters were more important than rainfall parameters in explaining crop cover in this region. During the monsoon season, cooler daytime and nighttime temperatures resulted in higher crop cover (Fig. 5b). This is likely because warmer temperatures have been shown to negatively impact the yields of several of the main crops grown during the monsoon season in the region, including BT cotton and rice (Baker et al., 1992; Buttar et al., 2012). Considering rainfall parameters, a greater number of rainy days and increased intensity of rainfall led to increased agricultural productivity in this region (Fig. 5b). This is likely due to several reasons. First, in this semi-arid region, water is a limiting factor for crop growth; so more frequent and more intense rainfall events lead to greater amounts of water available for plant uptake. Second, an increase in the number of rainy days also improves crop cover because it provides more regular watering of crops over the course of the season and reduces the number of days that crops are exposed to hot and dry conditions and experience water stress, which negatively impact yields (Hunsaker et al., 1998).

During the winter season, the negative effect of increased mean temperature was the most influential for crop cover in the Western India site (Fig. 5d). This is likely due to the negative impact of warmer temperature on the yields of several of the main crops grown during the winter season, including winter wheat and rice (Baker et al., 1992; Lobell et al., 2012). Regarding precipitation variables, greater daily intensity resulted in increased crop cover while a greater number of monsoon rainy days and a later monsoon start date resulted in reduced crop cover (Fig. $5 d$ ). This may be because a late monsoon start date is often associated with farmers switching to late season, longer duration crops like castor and long duration cotton (Jain, unpublished). This is because early season varieties, which require shorter growing periods, may not be a viable planting option when the monsoon onset occurs after the ideal date of sowing these crops. Furthermore, a greater intensity may be associated with increased crop cover during the winter season because more intense rainfall events may lead to increased irrigation storage in surface water sources (e.g. canals) due to a greater amount of runoff. It is important to note that the EVI range of the winter crop in this region had an upward trend over the course of our study period. This may be due to a variety of different factors, such as improved access to weather forecasts in the region, or high-yielding crop varieties that are less sensitive to climatic fluctuations.

\subsection{Broad climatic impact on agriculture and future directions}

Considering the future of agriculture in these two regions, projected precipitation changes may have a positive impact on crop cover but projected temperature increases will likely have a simultaneous negative impact. The monsoon crop in the Central India site is much more sensitive to precipitation variables (such as monsoon start date and end date) than that in the Western India site, and both sites are highly sensitive to temperature. Regional climate models predict that overall precipitation will increase all over India (Chaturvedi et al., 2012), with the number of rainy days and the intensity of rainfall events also increasing (Kumar et al., 2011). Given our model results for the monsoon season, an increase in the frequency and intensity of rainfall events will likely be associated with a positive effect on monsoon crop cover in the western India site (Fig. 5b) due to the reduction of periods of water stress, whereas the monsoon timing will play a more critical role in the Central India site (Fig. 5a) due to less flexible planting strategies.

The negative effects of increased daytime temperatures on monsoon crop productivity may counteract any precipitation benefit (Fig. 5a and b), given that climate models also project a simultaneous increase in temperature. Considering winter model results for both study sites, it is likely that future climate change will severely affect winter crop cover due to the negative impact of daytime warming on crop yields (Fig. $5 \mathrm{c}$ and d). This is particularly problematic since irrigation, which is one of the main technologies to buffer against climate shocks, especially in the Western India site (Fig. 3), will likely not be able to ameliorate these climate impacts given that it can do little to buffer against temperature shocks (Fishman, 2011; Taraz, 2012). Instead, if current crops begin to face systematic decreases in yields due to increasing temperature, farmers may have to look towards new climate-resilient crop varieties that are better able to thrive and resist the negative impacts of warming (U.S. Department of State, 2013).

Effects of increasing temperature on crop productivity vary widely depending on the timing and degree of temperature change, and crop type (Mearns et al., 1996; Lobell et al., 2012). Examining specific crop responses or the effects of timing of temperature change on crop productivity would require a more fine-scale spatio-temporal analysis, and was not addressed in this study. It should also be noted that the EVI anomaly reported in this study can be influenced by a change in crop type (e.g. a shift towards leafier crops), an increase in crop yield, or an increase in crop area. Identifying the exact contributing factor towards EVI anomaly is beyond the scope of this study, but methods to tease apart these differences are under development (Jain et al., unpublished data).

Our findings indicate that districts are notably different from each other in terms of sensitivity of crop cover to precipitation and temperature. While we did not directly include socio-economic variables in the mixed-effect models, it can be inferred from the results that district-level socio-economic factors, such as irrigation access, market influences, demography, and policies play critical role in agricultural production. For instance, our site in Western 
India has better groundwater irrigation coverage than the Central India site, leading to its lower sensitivity to climate variability, particularly precipitation variables. Groundwater irrigation offers increased buffering capacity against certain climate shocks given that it is insensitive to intra- and inter-annual climate fluctuations. The Western India site also has better access to the market and agricultural extension services than the Central India site. These may have reduced this region's sensitivity to climate fluctuations due to increased access to new seed varieties that may be more tolerant to climate variability. Better access to weather information might also help farmers plan cropping strategies that are better tailored to predicted weather patterns in a given year. It is important for future research to delve into these complex dynamics and identify the most important factors for future food security.

\section{Conclusions}

This study examined the climate sensitivity of crop cover in two Indian agro-eco subregions. We first quantified anomalies in crop cover for monsoon and winter seasons at pixel level using a 13-year EVI time series data (2000-2012). We then identified the most important climate variables associated with EVI values for peakseason crop cover, both for monsoon and winter, in each of these study sites. Considering the two questions we outlined in the introduction, different climate variables were found to be important in these two agro-ecological regions, and these differences may be attributed to differences in access to irrigation, market influences, and technology between these two regions. Specifically, we found that despite access to irrigation, crop cover in the Western India site showed substantial fluctuations during the monsoon, probably due to changing planting strategies, although this region was less sensitive to precipitation indices compared to the Central India site. Both sites showed strong sensitivity to daytime and nighttime temperatures for both seasons, especially to winter daytime warming. The Western India site was less sensitive to monsoon precipitation variability, likely due to increased access to groundwater irrigation that is insensitive to inter and intra-annual climate variability. The site in Central India, on the other hand, had less access to irrigation and also was dependent more on climate sensitive irrigation, like shallow dug-wells which are filled due to rainwater harvesting during the monsoon season. It is therefore crucial for future food production to have better access to sustainable irrigation and heat-tolerant high-yielding crop varieties.

\section{Acknowledgments}

This study was supported by NASA LCLUC grant\# 522363. We thank Harini Nagendra and Michael Bell for data and technical support. We also thank Pietro Ceccato, Andrew Robertson, the DeFries lab group, and two anonymous reviewers for constructive comments on this work.

\section{Appendix A. Supplementary data}

Supplementary data related to this article can be found at http:// dx.doi.org/10.1016/j.jenvman.2014.02.026.

\section{References}

Akaike, H., 1974. A new look at the statistical model identification. IEEE Trans. Auto. Cont. AC 19, 716-723.

Asada, H., Matsumoto, J., 2009. Effects of rainfall variation on rice production in the Ganges-Brahmaputra Basin. Clim. Res. 38, 249-260.

Auffhammer, M., Ramanathan, V., Vincent, J.R., 2012. Climate change, the monsoon, and rice yield in India. Clim. Change 111, 411-424.
Baker, J.T., Allen, L.H.J., Boote, J., 1992. Temperature effects on rice at elevated $\mathrm{CO}_{2}$ concentrations. J. Exp. Bot. 43, 959-964.

Barnwal, P., Kotani, K., 2013. Climatic impacts across agricultural crop yield distributions: an application of quantile regression on rice crops in Andhra Pradesh, India. Ecol. Econ. 87, 95-109.

Biradar, C.M., Xiao, X., 2011. Quantifying the area and spatial distribution of doubleand triple-cropping croplands in India with multi-temporal MODIS imagery in 2005. Int. J. Remote Sens. 32, 367-386.

Breiman, L., 2001. Random forests. Mach. Learn. 45, 5-32.

Brown, J.C., Jepson, W.E., Kastens, J.H., Wardlow, B.D., Lomas, J.M., Price, K.P., 2007. Multitemporal, moderate-spatial-resolution remote sensing of modern agricultural production and land modification in the Brazilian Amazon. GISci. Remote Sens. 44, 117-148.

Buttar, G.S., Jalota, S.K., Sood, A., Bhushan, B., 2012. Yield and water productivity of BT cotton (Gossypium hirsutum) as influenced by temperature under semi-arid conditions of north-western India: field and simulation study. Indian J. Agric. Sci. 82, 44-49.

Byjesh, K., Kumar, S.N., Aggarwal, P.K., 2010. Simulating impacts, potential adaptation and vulnerability of maize to climate change in India. Mitig. Adapt. Strat. Glob. Change 15, 413-431.

Chaturvedi, R.K., Joshi, J., Jayaraman, M., Bala, G., Ravindranath, N.H., 2012. Multimodel climate change projections for India under representative concentration pathways. Curr. Sci. 103, 791-802.

Chen, C., Baethgen, W.E., Robertson, A., 2013. Contributions of individual variation in temperature, solar radiation and precipitation to crop yield in the North China Plain, 1961-2003. Clim. Change 116, 767-788.

Cramer, W., 2006. Air pollution and climate change both reduce Indian rice harvests. Proc. Natl. Acad. Sci. USA 103, 19609-19610.

Das, R.J., 1999. Geographical unevenness India's Green revolution. J. Contemp. Asia 29, 167-186.

Dubash, N.K., 2002. Tubewell Capitalism: Groundwater Development and Agrarian Change in Gujarat. Oxford University Press.

Fan, S., Hazell, P., Haque, T., 2000. Targeting public investments by agro-ecological zone to achieve growth and poverty alleviation goals in rural India. Food Policy $25,411-428$.

Fishman, R.M., 2011. Climate Change, Rainfall Variability, and Adaptation through Irrigation: Evidence from Indian Agriculture. Available at: http://admin.water. columbia.edu/sitefiles/file/Uploads/Fishman_Irrigation_adaption.pdf (accessed 03.06.13.)

Freebairn, D.K., 1973. Income disparities in the agricultural sector: regional and institutional stresses. In: Poleman, T.T., Freebairn, D.K. (Eds.), Food Population and Employment. Praeger, New York, pp. 97-119.

Freebairn, D.K., 1995. Did the green revolution concentrate incomes? A quantitative study of research reports. World Dev. 23, 265-279.

Gadgil, S., Kumar, K.R., 2006. The Asian monsoon - agriculture and economy. In: Wang, B. (Ed.), The Asian Monsoon. Praxis and Springer, Berlin, Heidelberg, pp. $651-683$.

Gajbhiye, K.S., Mandal, C., 2000. Agro-ecological Zones, Their Soil Resource and Cropping Systems. National Bureau of Soil Survey and Land Use Planning, Nagpur.

Galford, G.L., Mustard, J.F., Melillo, J., Gendrin, A., Cerri, C.C., Cerri, C.E.P., 2008 Wavelet analysis of MODIS time series to detect expansion and intensification of row-crop agriculture in Brazil. Remote Sens. Environ. 112, 576-587.

Galford, G.L., Melillo, J., Mustard, J.F., Cerri, C.E.P., Cerri, C.C., 2010. The Amazon frontier of land-use change: croplands and consequences for greenhouse gas emissions. Earth Interact. 14, 1-24.

Government of India, 2013. Census of India 2011. Available at: http://www. censusindia.gov.in/2011census/hlo/PCA_Highlights/pca_highlights.html (accessed 03.06.13.)

Guiteras, R., 2007. The Impact of Climate Change on Indian Agriculture. Available at: http://www.colgate.edu/portaldata/imagegallerywww/2050/ImageGallery/ Guiteras\%20Paper.pdf (accessed 03.06.13.).

Guoju, X., Weixiang, L., Qiang, X., Zhaojun, S., Jing, W., 2005. Effects of temperature increase and elevated $\mathrm{CO}_{2}$ concentration, with supplemental irrigation, on the yield of rain-fed spring wheat in a semiarid region of China. Agric. Water Manag. 74, 243-255.

Hatfield, J.L., Prueger, J.H., 2010. Value of using different vegetative indices to quantify agricultural crop characteristics at different growth stages under varying management practices. Remote Sens. 2, 562-578.

Huete, A., Didan, K., Miura, T., Rodrigueza, E.P., Gaoa, X., Ferreira, L.G., 2002. Overview of the radiometric and biophysical performance of the MODIS vegetation indices. Remote Sens. Environ. 83, 195-213.

Hunsaker, D.J., Clemmens, A.J., Fangmeier, D.D., 1998. Cotton response to high frequency surface irrigation. Agric. Water Manag. 37, 55-74.

Indiastat, 2013. District-wise Irrigated Area under Crops. Available at: http://www. indiastat.com (accessed 03.06.13.).

IRI/LDEO Climate Data Library, 2013. Available at: http://iridl.ldeo.columbia.edu (accessed 03.06.13.).

Jain, M., Mondal, P., DeFries, R.S., Small, C., Galford, G.L., 2013. Mapping cropping intensity of smallholder farms: a comparison of methods using multiple sensors. Remote Sens. Environ. 134, 210-223.

Jalota, S.K., Kaur, H., Kaur, S., Vashisht, B.B., 2013. Impact of climate change scenarios on yield, water and nitrogen-balance and -use efficiency of rice-wheat cropping system. Agric. Water Manag. 116, 29-38. 
Kreft, I., DeLeeuw, J., 1998. Introducing Multilevel Modeling. Sage Publications Ltd, London.

Kumar, K.K., Kumar, R.K., Ashrit, R.G., Deshpande, N.R., Hansen, J.W., 2004. Climate impacts on Indian agriculture. Int. J. Climatol. 24, 1375-1393.

Kumar, K.K., Patwardhan, S.K., Kulkarni, A., Kamala, K., Rao, K.K., Jones, R., 2011. Simulated projections for summer monsoon climate over India by a highresolution regional climate model (PRECIS). Curr. Sci. 101, 312-326.

Lal, M., 2011. Implications of climate change in sustained agricultural productivity in South Asia. Reg. Environ. Change 11, 79-94.

Lobell, D.B., Burke, M.B., 2008. Why are agricultural impacts of climate change so uncertain? The importance of temperature relative to precipitation. Environ. Res. Lett. 3, 034007.

Lobell, D.B., Sibley, A., Ortiz-Monasterio, J.I., 2012. Extreme heat effects on wheat senescence in India. Nat. Clim. Change 2, 186-189.

Mearns, L.O., Rosenzweig, C., Goldberg, R., 1996. The effect of changes in daily and interannual climatic variability on Ceres-wheat: a sensitivity study. Clim. Change 32, 257-292.

Ministry of Agriculture, 2010. Crop Calendar of Major Crops. Government of India.

Morton, D.C., DeFries, R.S., Shimabukuro, Y.E., Anderson, L.O., Arai, E., del Bon Espirito-Santo, F., Freitas, R., Morisette, J., 2006. Cropland expansion changes deforestation dynamics in the southern Brazilian Amazon. Proc. Natl. Acad. Sci. USA 103, 14637-14641.

NOAA, 2013. The Global Land One-km Base Elevation Project. Available at: http:// www.ngdc.noaa.gov/mgg/topo/globe.html (accessed 03.06.13.).

O’Brien, K., Leichenko, R., Kelkar, U., Venema, H., Aandahl, G., Tompkins, H., Javed, A., Bhadwal, S., Barg, S., Nygaard, L., West, J., 2004. Mapping vulnerability to multiple stressors: climate change and globalization in India. Glob. Environ. Change 14, 303-313.

Ozdogan, M., 2010. The spatial distribution of crop types from MODIS data: temporal unmixing using independent component analysis. Remote Sens. Environ. 114, 1190-1204.

Pal, I., Al-Tabbaa, A., 2010. Long-term changes and variability of monthly extreme temperatures in India. Theor. Appl. Climatol. 100, 45-56.

Pal, I., Al-Tabbaa, A., 2011. Assessing seasonal precipitation trends in India using parametric and non-parametric statistical techniques. Theor. Appl. Climatol. $103,1-11$.

Pan, Y., Li, L., Zhang, J., Liang, S., Zhu, X., Sulla-Menashe, D., 2012. Winter wheat area estimation from MODIS-EVI time series data using the crop proportion phenology index. Remote Sens. Environ. 119, 232-242.

Peng, S., Ingram, K.T., Neue, H.U., Ziska, L.H., 1995. Climate Change and Rice. International Rice Research Institute (IRRI) and Springer, Manila, Philippines and Berlin, Germany.

Peng, S., Huang, J., Sheehy, J.E., Laza, R.C., Visperas, R.M., Zhong, X., Centeno, G.S., Khush, G.S., Cassman, K.G., 2004. Rice yields decline with higher night temperature from global warming. Proc. Natl. Acad. Sci. USA 101, 9971-9975.

Pittman, K., Hansen, M.C., Becker-Reshef, I., Potapov, P.V., Justice, C.O., 2010. Estimating global cropland extent with multi-year MODIS data. Remote Sens. 2, 1844-1863.

Prasad, A.K., Singh, R.P., Tare, V., Kafatos, M., 2007. Use of vegetation index and meteorological parameters for the prediction of crop yield in India. Int. J. Remote Sens. 28, 5207-5235.

Revadekar, J.V., Preethi, B., 2012. Statistical analysis of the relationship between summer monsoon precipitation extremes and foodgrain yield over India. Int. J. Climatol. 32, 419-429.
Rodell, M., Velicogna, I., Famiglietti, J.S., 2009. Satellite-based estimates of groundwater depletion in India. Nature 460, 999-1002.

Sakamoto, T., Yokozawa, M., Toritani, H., Shibayama, M., Ishitsuka, N., Ohno, H. 2005. A crop phenology detection method using time-series MODIS data. Remote Sens. Environ. 96, 366-374.

Sakamoto, T., Van Nguyen, N., Ohno, H., Ishitsuka, N., Yokozawa, M., 2006. Spatiotemporal distribution of rice phenology and cropping systems in the Mekong Delta with special reference to the seasonal water flow of the Mekong and Bassac rivers. Remote Sens. Environ. 100, 1-16.

Sakamoto, T., Cao, P.V., Nguyen, N.V., Kotera, A., Yokoza, M., 2009. Agro-ecological interpretation of rice cropping systems in flood-prone areas using MODIS imagery. Photogramm. Eng. Remote Sens. 75, 413-424.

Sankar, S., Kumar, M.R.R., Reason, C., 2011. On the relative roles of El Nino and Indian Ocean Dipole events on the Monsoon Onset over Kerala. Theor. Appl. Climatol. $103,359-374$.

Selvaraju, R., 2003. Impact of El Niño-southern oscillation on Indian foodgrain production. Int. J. Climatol. 23, 187-206.

Shiva, V., 1991. The Violence of the Green Revolution: Third World Agriculture, Ecology and Politics. Third World Network, Penang, Malaysia.

Singh, R.B., Kumar, P., Woodhead, T, 2002. Smallholder Farmers in India: Food Security and Agricultural Policy. FAO Regional Office for Asia and the Pacific, Bangkok, Thailand.

Subash, N., Sikka, A.K., Ram Mohan, H.S., 2011. An investigation into observational characteristics of rainfall and temperature in Central Northeast India - a historical perspective 1889-2008. Theor. Appl. Climatol. 103, 305-319.

Tao, F., Yokozawa, M., Zhang, Z., Hayashi, Y., Ishigooka, Y., 2008. Land surface phenology dynamics and climate variations in the North East China Transect (NECT), 1982-2000. Int. J. Remote Sens. 29, 5461-5478.

Taraz, V., 2012. Adaptation to Climate Change: Historical Evidence from the Indian Monsoon. Available at: http://www.econ.yale.edu/seminars/develop/tdw12 taraz-121015.pdf (accessed 03.06.13.).

U.S. Department of State, 2013. Heat Tolerant Wheat Will Withstand Global Warming. Available at: http://iipdigital.usembassy.gov/st/english/article/2013 04/20130409145443.html\#axzz2UnA6HOOm (accessed 03.06.13.).

USGS, 2013. Land Processes Distributed Active Archive Center. Available at: https:// lpdaac.usgs.gov/ (accessed 03.06.13.).

Wardlow, B.D., Kastens, J.H., Egbert, S.L., 2006. Using USDA crop progress data for the evaluation of greenup onset date calculated from MODIS 250-Meter data. Photogramm. Eng. Remote Sens. 72, 1225-1234.

Wardlow, B.D., Egbert, S.L., Kastens, J., 2007. Analysis of time-series MODIS 250 m vegetation index data for crop classification in the U.S. Central Great Plains. Remote Sens. Environ. 108, 290-310.

Wardlow, B.D., Egbert, S.L., 2008. Large-area crop mapping using time-series MODIS 250 m NDVI data: an assessment for the U.S. Central Great Plains. Remote Sens. Environ. 112, 1096-1116.

Wheeler, T.R., Craufurd, P.Q., Ellis, R.H., Porter, J.R., Vara Prasad, P.V., 2000. Temperature variability and the yield of annual crops. Agric. Ecosyst. Environ. 82, 159-167.

Wu, R., Kirtman, B.P., 2004. Impacts of the Indian ocean on the indian summer Monsoon-ENSO relationship. J. Clim. 17, 3037-3054.

Xiao, J., Moody, A., 2004. Trends in vegetation activity and their climatic correlates: China 1982 to 1998. Int. J. Remote Sens. 25, 5669-5689. 